\title{
Nutritional characterization of some natural plants used in poultry nutrition
}

\author{
Turcu Raluca Paula*1, Olteanu Margareta1, Untea Arabela \\ Elena' ${ }^{1}$, Saracila Mihaela1, Varzaru Iulia' ${ }^{1}$, Vlaicu Petru Alexandru${ }^{1}$ \\ ${ }^{*}$ Corresponding author: raluca.turcu@ibna.ro
}

${ }^{1}$ Laboratory of Chemistry and Nutrition Physiology, National Research and Development Institute for Biology and Animal Nutrition, Calea Bucuresti no. 1, Balotesti, Ilfov, 077015, Romania

\section{ABSTRACT}

Current nutritional strategies of livestock industry are focused on evaluating the effects of terrestrial sources rich in natural bioactive compounds that can be used in farm animal feed and the subsequent implications on the quality of resulting animal products. In this context, the present study aimed to characterize from a nutritional point of view some natural plants used as phyto-additives in poultry nutrition: oregano, mint, basil, sage, fenugreek, thyme, turmeric, cumin and rosemary. The results of this study on plants nutritional evaluation showed a varied proximate analysis. Of all the plants, cumin, fenugreek and basil were the richest source of crude protein. Thyme had a large ether extractives content, followed by rosemary, sage and cumin. The obtained results revealed that oregano has the strongest antioxidant capacity ( $849.77 \mathrm{mmols}$ equiv. asc. acid; $863.57 \mathrm{mmols}$ equiv. vit. E), the highest total polyphenols concentration (86.77 mg GAE/g) and lutein and zeaxanthin $(304.23 \mu \mathrm{g} / \mathrm{g})$ of the analysed plants. Nevertheless, all plants had high concentration of total polyphenols, except cumin, a large amount of xanthophylls and vitamin E. After oregano, sage and thyme have been noted for their antioxidant capacity and major antioxidant compounds. Basil and sage revealed the highest amount of essential trace elements.

Keywords: poultry, phyto-additives, polyphenols, vitamin E

\section{INTRODUCTION}

Nowadays, most modern diets are based on natural products and ingredients. Knowledge of a diverse, safe and quality diet must be constantly improved, given that the composition and consumption of food are important segments of food industry. At the same time, the food availability for humans, 
in competition with animal feed, is insufficient so that it is necessary to capitalize on the full potential of existing resources and identify other unknown and / or less known (FAO and WHO, 2020).

The current nutritional strategies of livestock industry are focused on evaluating the effects of terrestrial sources rich in natural bioactive compounds that can be used in farm animal feed and the subsequent implications on the quality of resulting animal products (Arroyo et al., 2019). Several herbs, some of them traditionally used since ancient times by humans, in the form of spices, herbs and their essential oils, can be used in animal nutrition. The efficient use of bioactive compounds from these natural plants, given their traditional use, can lead to new food applications development (Diniz do Nascimento et al., 2020). Among botanicals widely used in traditional medicine are: oregano, mint, basil, sage, fenugreek, thyme, turmeric, cumin and rosemary, plants studied for this paper.

Oregano (Origanum vulgare L.) is an aromatic perennial herb from Lamiaceae family, which has stood out over time due to its antioxidant and antimicrobial properties against pathogenic microorganisms such as Escherichia coli, Staphylococcus aureus or Salmonella typhimurium (ArcilaLozano et al., 2004). Oregano and its oil are currently used to replace synthetic additives, making it a good alternative to antibiotics (Windisch et al., 2008). Park et al., (2015) highlighted the positive effects of oregano use in poultry nutrition on production parameters, immune system, gastrointestinal microflora modulation, or pathogens inhibition.

Mint (Mentha spp.) is a genus of about 25-30 species of plants in Lamiaceae family, also an aromatic and medicinal herb, spreading worldwide, with antioxidant, antimicrobial and antifungal properties (Singh and Pandey, 2018). The use of mint and its oil in poultry diets can improve the production parameters (Verma et al., 2020), meat sensory quality (flavour, tenderness and juiciness) (Quinche et al., 2019) and lipid oxidation of eggs (Aydin and Bölükbașl, 2020).

Basil (Ocimum basilicum L.) is an herbaceous plant, member of Lamiaceae family, used for their antimicrobial, antioxidant, anti-inflammatory, antibacterial and antiviral properties. Basil and its oil have a good efficiency against intestinal parasites and bacterial infections (Alabi et al., 2018). Recent studies (Sheoran et al., 2017) highlighted the basil potential to increase the production performance and immune status of birds when is used in their feed.

Sage (Salvia officinalis) is a plant from Lamiaceae family with good antioxidant and antimicrobial properties. It has been shown that the inclusion of sage in broiler diets led to a significant reduction of plasma total cholesterol, triglycerides and low-density lipoprotein (Rasouli et al., 2019), and also reduced the total bacterial count and coliform bacteria in the intestines of the broiler (Majid et al., 2019). 
Fenugreek (Trigonella foenum-graecum L.) is an annual plant herb from the Fabaceae family with antimicrobial, antifungal and antiviral properties. Recent research has shown that the use of fenugreek in laying hen diets improved their immune system, feed conversion ratio (Samani et at., 2020) and egg production adversely affecting their quality (Wahab et al., 2019).

Thyme (Thymus vulgaris L.) is a perennial aromatic plant, member of mint family, Lamiaceae, with strong antimicrobial and antiseptic properties. There is information in the literature (Yalçin et al., 2020) regarding the potential of antioxidant compounds from thyme that can prevent lipid peroxidation of egg yolk, reduce the cholesterol and total saturated fatty acids of yolk and improved omega-3 fatty acid content when it is included in hen diets.

Turmeric (Curcuma longa L.) is a perennial plant, member of ginger family Zingiberaceae with many positive effects on animal health and welfare. The bioactive compounds of turmeric, make it an excellent feed additive for animal nutrition due to its antioxidant, antibacterial, anti-inflammatory and antiviral, properties (Dono, 2013). Kosti et al., (2020) reported an increase in egg production and Lactobacillus spp. counts when they supplemented laying hen diets with turmeric powder.

Cumin (Cuminum cyminum) is a flowering plant from Apiaceae family with antioxidant, antimicrobial and anticholesterol properties (Hajati et al., 2014). It has been shown that the use of cumin in broiler diets improved body weight gain, feed conversion ratio, blood biochemistry (Rafiee et al., 2014) and has beneficial effects on chemical and physical attributes of meat (Majid et al., 2020).

Rosemary (Salvia Rosmarinus) is a woody, perennial herb from Lamiaceae family with strong antioxidant properties. Polat et al., (2011) reported a decrease in serum cholesterol level for broilers fed with rosemary, concluding that rosemary diet may positively influence the renal and hepatic function of birds. Similar results on serum cholesterol level were obtained in a study Alagawany et al., (2015) on laying hens, and in addition, the use of rosemary improved egg numbers, egg mass, yolk percent and yolk-to-albumen ratio, with a decrease in albumen percent.

The present study aimed to characterize from a nutritional point of view some natural plants used as phyto-additives in poultry nutrition.

\section{MATERIALS AND METHODS}

The plants characterized in this study were purchased in dried form from a local producer who grows these plants in the south (Măcrișului Valley Farm, Ialomița County) and southwest (Zătreni Valley Farm, Vâlcea County) of the Romania. The sampling and conditioning of plants were performed by producer. 
In order to determine the total polyphenol content (TP) and total antioxidant capacity (TAC), it was necessary to obtain extracts from the studied plants. According to Untea et al., (2020), $1 \mathrm{~g}$ of dried plant powder was extracted in $10 \mathrm{ml}$ of methanol and kept on a rotary shaker for 24 hours in the dark. The extract thus obtained was centrifuged for 10 minutes at $1500 \mathrm{rpm}$, and the resulting supernatant was used for analysis.

\section{Proximate composition}

Standardized methods according to Regulation (EC) no. 152/2009 and ISO standards were used in order to determine the main nutrients concentration from plants. Crude protein (CP) was determined by Kjeldahl method, according to SR EN ISO 5983-2: 2009, using a semiautomatic Kjeltec 2300 system-Tecator Instruments (Sweden). Ether extractives (EE) were determined by organic solvent extraction method according to SR ISO 6492: 2001, using a Soxtec 2055 Foss Tecator (Sweden). Crude fibre (CF) was determined by intermediary filtration method according to SR EN ISO 6865: 2002, using an automatic analyser Fibertec 2010, (Foss Tecator, Sweden). Crude ash (Ash) was determined by gravimetric method according to SR EN ISO 2171: 2010, using a Caloris CL 1206 oven (Romania).

\section{Content of total polyphenols (TP)}

The total polyphenol content of sample extracts was performed spectrophotometrically using an improved version of Folin-Ciocalteu method, as described by Untea et al., (2020). The results regarding the total polyphenol content were expressed as mg gallic acid equivalents per gram of dried sample (mg GAE/g).

\section{Total Antioxidant Capacity (TAC)}

The total antioxidant capacity of the extracts was determined using the phosphomolybdenum method as described by Untea et al., (2020). The absorbance was recorded at $695 \mathrm{~nm}$ and the results were expressed as ascorbic acid equivalents for hydrophilic compounds (mmols equiv. asc acid) and vitamin $\mathrm{E}$ equivalents for lipophilic compounds (mmols equiv. vit E) per gram of dried sample. For turmeric, cumin and rosemary was used the DPPH radical-scavenging activity method as described by Varzaru et al., (2020). The absorbance of the solution was recorded at $517 \mathrm{~nm}$ using a spectrophotometer (Jasco V-530, Japan Servo Co. Ltd., Japan). Trolox was used as standard. The results were expressed as $\mathrm{mM}$ Trolox equivalents (mmols equiv. Trolox).

\section{Lutein and zeaxanthin determination}

The content of lutein and zeaxanthin was determined using a highperformance liquid chromatograph (Perkin Elmer 200 series, Shelton, CT, 
USA) equipped with UV detector (445 nm). Chromatographic determination was performed under isocratic conditions according to the method described by Varzaru et al., (2020). The results were expressed as as $\mu \mathrm{g} / \mathrm{g}$ of dried sample.

\section{Vitamin $E$ determination}

The vitamin E concentration was determined using a high-performance liquid chromatograph (HPLC Finningan Surveyor Plus, Thermo-Electron Corporation, Waltham, MA) equipped with PDA-UV detector (292 nm). Chromatographic determination was performed under isocratic conditions according to the method described in Regulation (EC) no. 152/2009 and by Varzaru et al., (2020). The results were expressed as $\mu \mathrm{g} / \mathrm{g}$ of dried sample.

\section{Trace elements determination}

The calcium (Ca) was determined by the titrimetric method, according to SR ISO 6490-1:2006 and the phosphorus (P) was determined spectrophotometrically, according to Regulation (EC) no. 152/2009, using a molecular absorption spectrophotometer Jasco V-530. Copper ( $\mathrm{Cu}$ ), iron (Fe), manganese $(\mathrm{Mn})$ and zinc $(\mathrm{Zn})$ were determined according to the method described by Untea et al. (2012) using atomic absorption spectrometry method. The results were expressed as $\mu \mathrm{g} / \mathrm{g}$ of dried sample.

\section{Statistical analysis}

The obtained results were calculated using descriptive data analysis from Microsoft Excel for Windows.

\section{RESULTS AND DISCUSSION}

\section{Proximate analysis of plants}

The results of proximate analysis of plants are given in Table 1 . The highest concentration of crude protein was recorded in cumin, which also had the highest content of crude fibre from the analysed plants. High concentrations of crude protein were also found in fenugreek and basil, the latter having at the same time the highest ash content. Thyme was noted with a large ether extractives content, compared to the other plants analysed, followed by rosemary, sage and cumin.

The literature includes various results on proximate analysis of these plants studied in the present paper. This is due to the variety of plants, geographical origins, environmental and climatic conditions, soil type, harvesting time, temperature and period of drying (Carvalho-Filho et al., 2006). El-Ghorab et al., (2010) reported in a comparative study on chemical composition and antioxidant activity of some plants including cumin, a content of $15.70 \% \pm 0.32$ crude protein; $11.50 \% \pm 0.38$ ether extractives; 
$37.20 \% \pm 0.37$ crude fibre and $9.30 \% \pm 0.24$ crude ash. Previous studies (Seidavi et al., 2020) on black cumin seeds using in broiler diets have shown their positive effects on production performance at a 3-5\% level of inclusion in the diet. The inclusion of black cumin oil (1-2\%) in laying hen diets reduced the number of intestinal E. coli. and also improved the production performance of birds, namely egg mass and egg quality overall.

Regarding the fenugreek, available data (Naidu et al., 2011) highlights a content of $27.57 \mathrm{~g} \pm 0.09$ crude protein; $6.71 \mathrm{~g} \pm 0.01$ ether extractives and 3.90 $\mathrm{g} / 100 \mathrm{~g} \pm 0.14 \mathrm{ash}$. It has been shown that the use of fenugreek seeds in broiler diets, especially at an inclusion rate of $2.0 \%$, significantly increased productive performance. At the same time, abdominal fat was reduced and drumstick meat weight and dressed breast, thigh, carcass was improved. Considering the economic efficiency of new feeds, the inclusion of fenugreek seeds in broiler diets led to a reduction in their costs and improved production (Toaha et al., 2016).

Table 1. Proximate analysis of plants

\begin{tabular}{ccccc}
\hline Sample & \multicolumn{2}{c}{ Crude protein Ether extractives } & $\begin{array}{c}\text { Crude } \\
\text { fibre }\end{array}$ & $\begin{array}{c}\text { Crude } \\
\text { ash }\end{array}$ \\
\cline { 2 - 5 } & \multicolumn{3}{c}{$\%$} & \\
\cline { 2 - 5 } Oregano & 11.95 & 1.88 & 9.28 & 8.95 \\
Mint & 17.09 & 1.65 & 12.30 & 13.81 \\
Basil & 18.06 & 2.56 & 10.88 & 17.34 \\
Sage & 14.19 & 3.40 & 20.24 & 10.23 \\
Fenugreek & 18.71 & 1.24 & 22.94 & 11.39 \\
Thyme & 14.67 & 7.32 & 24.63 & 9.69 \\
Turmeric & 10.91 & 2.86 & 5.35 & 9.29 \\
Cumin & 21.58 & 3.06 & 30.09 & 5.82 \\
Rosemary & 5.35 & 3.62 & 22.25 & 6.61 \\
\hline
\end{tabular}

Antioxidant capacity and major antioxidant compounds of the plants extracts

As can be seen in Table 2, the plant with the strongest antioxidant capacity and major antioxidant compounds overall was oregano, followed by sage and thyme. Jałoszyński et al., (2008) evaluated the antioxidant activity of dehydrated oregano by three methods: freeze drying, convective drying and vacuum-microwave drying. The obtained results ranged between $63.96 \mathrm{mg}$ $394.06 \mathrm{mg} \mathrm{GAE} / 100 \mathrm{~g}$, the conclusion of the study being that the method used for plant drying greatly influences the total polyphenols concentration. Spiridon et al., (2012) reported for oregano a polyphenol content of $67.8 \pm 3.41$ $\mathrm{mg} \mathrm{GAE} / \mathrm{g}$; flavonoids $31.6 \pm 4.25 \mathrm{mg} \mathrm{R} / \mathrm{g}$ and an antioxidant activity of $114 \pm 4.18 \mathrm{mg} \mathrm{AA} / \mathrm{g}$. 
Available literature data (Ri et al., 2017) showed that oregano powder supplementation in broiler nutrition improved average daily food intake and thus the average daily gain. A decrease in the content of malondialdehyde and higher total antioxidant activity (T-AOC) in the serum of broilers were also observed. In terms of meat quality, oregano can slow down the lipid peroxidation processes at an inclusion rate of $2.5-5 \%$, although it also influences the meat color parameters, but without affecting their sensory quality and the level of acceptability by consumers (Velasco et al., 2017). Beneficial effects of oregano using (powder and oil) in broiler diets have also been reported by Vlaicu et al., (2020). The inclusion in diets of $0.01 \%$ oregano oil level and $0.005 \%$ oregano oil together with $1 \%$ oregano powder significantly $(\mathrm{p}<0.05)$ improved the overall production performance. The number of Enterobacteriaceae and Escherichia coli count was significantly lower in the intestine of the experimental groups, while the number of Lactobacillus spp. was significant higher compared to the control group. Similar results of dietary supplementation of laying hen diets with oregano essential oil have been reported by Denli et al., (2019). The use of oregano essential oil improved the egg weight and decreased the egg shell bacterial contamination through the reduction of Escherichia coli and Coliforms. It is also known that oregano improves the intestinal microflora of broilers under heat stress (Turcu et al., 2018).

Table 2. Antioxidant capacity and major antioxidant compounds of the plants extracts

\begin{tabular}{cccccc}
\hline Sample & $\begin{array}{c}\text { Total } \\
\text { polyphenols } \\
(\mathrm{mg} \mathrm{GAE} / \mathrm{g})\end{array}$ & $\begin{array}{c}\text { TAC } \\
\text { (mmols } \\
\text { equiv. asc. } \\
\text { acid) }\end{array}$ & $\begin{array}{c}\text { TAC } \\
\text { (mmols equiv. } \\
\text { vit. E) }\end{array}$ & $\begin{array}{c}\text { Lutein and } \\
\text { zeaxanthin } \\
(\mu \mathrm{g} / \mathrm{g})\end{array}$ & $\begin{array}{c}\text { Vitamin E } \\
(\mu \mathrm{g} / \mathrm{g})\end{array}$ \\
\hline Oregano & 86.77 & 849.77 & 863.57 & 304,23 & 134,12 \\
Mint & 25.19 & 301.42 & 264.43 & 196,35 & 77,85 \\
Basil & 11.37 & 313.61 & 275.50 & 230,31 & 113,33 \\
Sage & 50.20 & 575.30 & 562.67 & 257,66 & 160,76 \\
Fenugreek & 3.74 & 175.86 & 128.80 & 165,79 & 88,13 \\
Thyme & 34.13 & 442.48 & 416.72 & 236,81 & 188,93 \\
Turmeric & 21.36 & - & - & 3,37 & 12,02 \\
Cumin & 6.73 & - & - & 6,24 & 23,76 \\
Rosemary & 53.42 & - & - & 70,63 & 156,12 \\
\hline
\end{tabular}

In contrast to the total polyphenol content obtained in this study for fenugreek, Naidu et al., (2011) reported a concentration of $85.88 \pm 0.01 \mathrm{mg}$ $\mathrm{GAE} / \mathrm{g}$. Results of other research highlighted a total polyphenols content of sage that varies depending on harvesting time between $85.33 \pm 3.08 \mathrm{mg}$ GAE and $110.52 \pm 4.64 \mathrm{mg} \mathrm{GAE} / \mathrm{g}$; for rosemary $94.29 \pm 0.59 \mathrm{mg} \mathrm{GAE}$ and 104.44 \pm 2.55 mg GAE/g (Baydar et al., 2009). Regarding mint, Kalemba-Drożdż 
et al., (2020) reported 8.90-10.68 $\mathrm{mg} / 100 \mathrm{~g}$ polyphenols concentration, respectively $0.03-0.18 \mu \mathrm{g} / 100 \mathrm{~g}$ carotenoids. Similar results to those obtained in this study for basil were reported by Nguyen et al., (2010) who tested three cultivars of basil (Ocimum basilicum L.) leaves: $8.37 \pm 1.76 \mathrm{mg} \mathrm{GAE} / \mathrm{g}$ for Sweet Thai; $11.58 \pm 3.34 \mathrm{mg} \mathrm{GAE} / \mathrm{g}$ for Dark Opal, and 12.54 $\pm 1.83 \mathrm{mg}$ GAE/g for Genovese.

Majid et al., (2019) included different levels of fenugreek and sage in broiler diets, obtaining an improvement in production performance and broiler health, highlighted by the numbers of total bacteria and colon bacteria decreasing. The results of another study (Abbas, 2010) showed that broilers fed with basil ( $3 \mathrm{~g} / \mathrm{kg}$ diet $)$ had significantly higher body weight compared to those who received fenugreek ( $3 \mathrm{~g} / \mathrm{kg}$ diet). In fact, both diets significantly improved serum cholesterol levels compared to control diet. It would suggest that the supplementation of broiler diets with basil improved productive performance. It has been shown that supplementing broiler diets with black cumin seed, fenugreek and turmeric powder at (1 and $2 \mathrm{~g} / \mathrm{kg}$ diet) improved breast meat yield. The inclusion of fenugreek powder had a significant effect on gizzard and giblet ratio and reduced the abdominal fat ratio, compared to the control group and turmeric diet. However, turmeric can be used for its beneficial results on carcass yield and lean breast meat (Yesuf et al., 2017). In another study (Giannenas et al., 2016) sage (0.5\%) and oregano (5\%) essential oil were used as natural antioxidants in broiler diets. The obtained results indicated a slowdown in the lipid peroxidation processes for breast and thigh meat, corroborated with the inclusion rate in diet. Kishawy et al., (2016) evaluated the effects of sage oil and peel extract (PPE) on reducing the damaging effect of rancid soybean oil in broiler diets. The use of sage oil improved weight gain and feed conversion ratio, decreased the serum cholesterol, triacylglycerols and abdominal fat, and improved the immunity parameters of broilers.

DPPH radical-scavenging activity of turmeric, cumin and rosemary can be seen in Figure 1. Of all the three plants analysed, turmeric stood out with the highest total antioxidant capacity, followed by cumin. Research (Durrani et al, 2006) regarding the inclusion of turmeric in broiler diets reported improved production performance (chick weight gain, feed conversion) and better economic efficiency. Also, the inclusion of different turmeric levels in broiler diets $(0.25 \% ; 0.50 \% ; 1 \%)$ revealed that $0.50 \%$ turmeric improved body weight, feed conversion ratio and feed consumption. Significant differences were recorded for dressing percentage in all treatments, compared to the control (Abd Al-Jaleel, 2012). Similar results were reported by Al-Kassie et al., (2011) who evaluated the effect of the mixture of cumin and turmeric in broiler diets at different levels of inclusion $(0.25 \% ; 0.50 \% ; 0.75 \%$ and $1 \%$ ). The inclusion of cumin and turmeric mixture at levels of $0.75 \%$ and $1 \%$ in diets improved body weight gain, feed intake and feed conversion ratio. At the 
same time, this mixture reduced the cholesterol level, $\mathrm{Hb}, \mathrm{RBC}, \mathrm{WBC}$, and $\mathrm{H} / \mathrm{L}$ ratio concentration. In a comparative study (Ashayeri Zadeh et al., 2009) the effect of garlic powder, black cumin seeds powder and wild mint powder were tested. The broilers fed with black cumin seeds powder had the highest body weight gain and feed conversion ratio compared with the other diets. Also, this diet led to the lowest abdominal fat percentage, the highest carcass and breast percent, compared to the control and wild mint diets. Gurbuz and Ismael (2016) evaluated the effect of peppermint and basil $(0.5 \% ; 1 \% ; 1.5 \%)$ as a feed additive in broiler diets. The obtained results showed significant higher production performances and liver weight in $1.5 \%$ peppermint diet. The authors suggested that using peppermint and basil can improve the growth performance and feed conversion ratio of broilers.

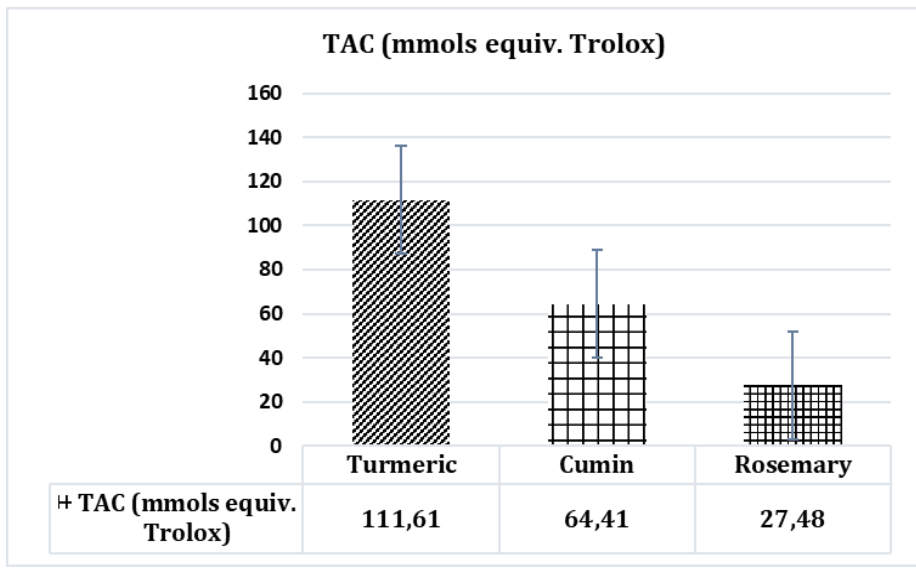

Figure 1. Total antioxidant capacity of the plants extracts (mm equiv. Trolox)

\section{Essential trace elements composition of plants}

From the recorded results (Table 3), it was observed that basil is a plant rich in essential trace elements, obtaining in this study the highest level of calcium, manganese, zinc and copper. The highest content of basil minerals is directly related with the highest crude ash concentrations from the studied plants. High levels of trace elements were also determined for sage which had the large amount of iron and remarkable levels of zinc and copper from the analysed plants. Results of previous studies showed for basil a content of 2.163.09\% Ca; 0.40-64\% P (Nurzyńska-Wierdak et al., 2011); $205.30 \mathrm{mg} / \mathrm{kg} \mathrm{Fe;}$ $22.20 \mathrm{mg} / \mathrm{kg} \mathrm{Mn}$ and $272.80 \mathrm{mg} / \mathrm{kg} \mathrm{Zn}$ (Leal et al., 2008). Kalemba-Drożdż et al., 2020 reported a content of 0.18-9.70 mg Ca; 0.04-0.21 mg Fe and 0.01-0.04 $\mathrm{mg} \mathrm{Zn} \mathrm{/100} \mathrm{ml} \mathrm{sample} \mathrm{of} \mathrm{mint} \mathrm{(fermented,} \mathrm{macerate,} \mathrm{tincture,} \mathrm{decoction).}$

Farm activities are related with environmental pollution the with nitrogen $(\mathrm{N})$, phosphorus (P) and traces element that animals excrete. One of the measures to prevent pollution is to reduce the elements excretion by 
improving their bioavailability and the inclusion of phyto-additives in farm animal diets (Lu et al., 2017).

Table 3. Essential trace elements composition of plants

\begin{tabular}{ccccccc}
\hline Sample & $\mathbf{C a}$ & $\mathbf{P}$ & $\mathbf{C u}$ & $\mathbf{F e}$ & $\mathbf{M n}$ & $\mathbf{Z n}$ \\
\cline { 2 - 7 } & & $\mathbf{0}$ & & & $\mathbf{\mu g} / \mathbf{g}$ & \\
\hline Oregano & 1.54 & 0.37 & 7.86 & 317.03 & 60.79 & 24.98 \\
Mint & 2.22 & 0.36 & 9.62 & 337.54 & 101.94 & 28.22 \\
Basil & 3.29 & 0.45 & 11.49 & 326.77 & 139.98 & 39.32 \\
Sage & 1.34 & 0.44 & 12.05 & 903.38 & 45.20 & 38.41 \\
Fenugreek & 1.09 & 0.55 & 7.11 & 322.63 & 29.34 & 31.07 \\
Thyme & 0.76 & 0.43 & 7.16 & 818.00 & 39.65 & 33.06 \\
Turmeric & 0.32 & 0.43 & 6.23 & 618.72 & 84.18 & 27.53 \\
Cumin & 0.76 & 0.56 & 9.14 & 85.53 & 29.28 & 36.29 \\
Rosemary & 1.41 & 0.08 & 3.85 & 371.38 & 20.20 & 31.22 \\
\hline
\end{tabular}

Note: $\mathrm{Ca}=$ calcium, $\mathrm{P}=$ phosphorus; $\mathrm{Cu}=$ copper; $\mathrm{Fe}=$ iron; $\mathrm{Mn}=$ manganese; $\mathrm{Zn}=$ zinc.

Some of the studied plants can be considered good sources of trace minerals (ex. sage and thyme for iron or mint and basil for manganese) even if the bioavailability of minerals from vegetal sources is considered to be very low (Lopez et al., 2002) due to their rich phytate content. Other plants can stimulate the absorption of mineral from animals' diet by other pathways, including components with antioxidant potential (ex. oregano).

\section{CONCLUSION}

The results of this study showed that cumin, fenugreek and basil were the richest source of crude protein, oregano, sage and thyme have the strongest antioxidant potential and basil and sage revealed the highest amount of essential trace elements.

\section{ACKNOWLEDGEMENTS}

This work was funded by Romanian Ministry of Agriculture and Rural Development through the project ADER 9.1.2./2019.

\section{REFERENCES}

Abbas R.J., 2010. Effect of using fenugreek, parsley and sweet basil seeds as feed additives on the performance of broiler chickens. International Journal of Poultry Science, 9(3): 278-282.

Abd Al-Jaleel R.A., 2012. Use of turmeric (Curcuma longa) on the performance and some physiological traits on the broiler diets. Iraqi Journal of Veterinary Medicine, 36(1): 51-57. 
Alabi 0.0., Shoyombo A.J., Animashahun R.A. and Olawoye S.O., 2018. The benefits of basil leaves as natural medicine in livestock production. In: Proc. 43 ${ }^{\text {rd }}$ Annual Conference of the Nigerian Society for Animal Production, FUT Owerri.

Alagawany M. and Abd El-Hack M.E., 2015. The effect of rosemary herb as a dietary supplement on performance, egg quality, serum biochemical parameters, and oxidative status in laying hens. Journal of Animal and Feed Sciences, 24: 341-347.

Al-Kassie G.A.M., Mohseen A.M., Abd-AL-Jaleel R.A., 2011. Modification of produc-tive performance and physiological aspects of broilers on the addition of a mixture of cumin and turmeric to the diet. Research Opinions in Animal \& Veterinary Sciences, 1: 31-34.

Arcila-Lozano C.C., Loarca-Piña G., Lecona-Uribe S., González de Mejía E., 2004 Oregano: properties, composition and biological activity. Archivos Latinoamericanos de Nutricion., 54(1): 100-111.

Arroyo B.J., Santos A.P., Melo E.D.A.D., Campos A., Lins L., Boyano-Orozco L.C., 2019. Bioactive compounds and their potential use as ingredients for food and its application in food packaging. Elsevier: Amsterdam, The Netherlands, Chapter 8, 143-156.

Aydın A. and Bölükbașı Ș.C., 2020. Effect of Supplementation of Hen Diet with Pennyroyal Extract (Mentha pulegium) on Performance, Egg Quality and Yolk TBARS Values. Pakistan Journal of Zoology, 52(3): 10451051.

Baydar H., Ozkan G., Erbas S., Altindal D., 2009. Yield, chemical composition and antioxidant properties of extracts and essential oils of sage and rosemary depending on seasonal variations. Acta Horticultura, 826: 383-389.

Carvalho-Filho J.L.S., Blank A.F., Alves P.B., Ehlert P.A.D., Melo A.S., Cavalcanti S.C.H., Arrigoni-Blank M.F., Silva-Mann R., 2006. Influence of the harvesting time, temperature and drying period on basil (Ocimum basilicum L.) essential oil. Revista Brasileira de Farmacognosia, 16(1): 24-30.

Commission Regulation (EC) No. 152/2009 laying down the methods of sampling and analysis for the official control of feed.

Denli M., Vural A., Yesilmen Alp S., 2019. The influence of oregano essential oil on egg quality and egg shell contamination of laying hens kept in furnished cages. Scientific papers. Series d. Animal science, LXII(2): 4852.

Diniz do Nascimento L., Moraes A.A.B., Costa K.S., Pereira Galúcio J.M., Taube P.S., Costa C.M.L., Neves Cruz J., de Aguiar Andrade E.H., Faria L.J.G., 2020. Bioactive natural compounds and antioxidant activity of essential oils from spice plants: New findings and potential applications. Biomolecules, 10 (7): 935-988. 
Dono N.D., 2013. Turmeric (Curcuma longa Linn.) supplementation as analternative to antibiotics in poultry diets. Indonesian Bulletin of Animal and Veterinary Sciences, 23(1): 41-49.

Durrani F.R., Mohammad I., Asad S., Suhail S.M., Chand N. and Durrani Z., 2006. Effect of different levels of feed added turmeric (Curcuma longa) on the performance of broiler chicks. Journal of Agricultural and Biological Science, 1(2): 9-11.

El-Ghorab H., Nauman M., Anjum F.M., Hussain S., Nadeem M., 2010. Comparative study on chemical composition and antioxidant activity ofginger (Zingiber officinale) and cumin (Cuminum cyminum). Journal of Agricultural and Food Chemistry, 58(14): 8231-8237.

FAO and WHO, 2020. The Future of food safety: Transforming knowledge into action for people, economies and the environment - Transforming knowledge into action for people, economies and the environment. Technical summary by FAO and WHO. Rome.

Giannenas I., Karamoutsios A., Bartzanas T., Tsinas A., Tzora A., Skoufos I., 2016. Oregano and sage essential oils improve antioxidant status of raw and cooked breast and thigh chicken meat. Agro Food Industry Hi Tech, 27: 10-14.

Gurbuz Y., Ismael A.I., 2016: Effect of peppermint and basil as feed additive onbroiler performance and carcass characteristics. Iranian Journal of Applied Animal Science 6: 149-156.

Hajati H., Hassanabadi A. and Ahmadian F., 2014. Application of medicinal plants in poultry nutrition. Journal of Medicinal Plants and Byproducts, 3(1): 1-12.

Jałoszyński K., Figiel A., Wojdyło A., 2008. Drying kinetics and antioxidant activity of oregano. Acta Agrophysica, 11(1): 81-90.

Kalemba-Drozdz M., Kwiecien I., Szewczyk A., Cierniak A. and GrzywaczKisielewska A., 2020. Fermented vinegars from apple peels, raspberries, rosehips, lavender, mint, and rose petals: the composition, antioxidant power, and genoprotective abilities in comparison to acetic macerates, decoctions, and tinctures. Antioxidants, 9: 1121.

Kishawy A.T., Omar A.E., Gomaa A.M., 2016. Growth performance and immunity of broilers fed rancid oil diets that supplemented with pomegranate peel extract and sage oil. Japanese Journal of Veterinary Research, 64(2): S31-S38.

Kosti D., Dahiya D.S., Dalal R., Tewatia B.S., Vijayalakshmy K., 2020. Role of turmeric supplementation on production, physical and biochemical parameters in laying hens, World's Poultry Science Journal, 1-3.

Leal P.F., Maia N.B., Carmello Q.A.C., Catharino R.R., Eberlin M.N., Meireles M.A.A., 2008. Sweet basil (Ocimum basilicum) extracts obtained by supercritical fluid extraction (SFE): Global yields, Chemical 
composition, Antioxidant activity, and estimation of the cost of manufacturing. Food and Bioprocess Technology, 1: 326-338.

Lopez H.W., Leenhardt F., Coudray C., Remesy C., 2002. Minerals and phytic acid interactions: is it a real problem for human nutrition? International journal of food science \& technology, 37(7): 727-739.

Lu L., Liao X., Luo X., 2017. Nutritional strategies for reducing nitrogen, phosphorus and trace mineral excretions of livestock and poultry. Journal of Integrative Agriculture, 16(12): 2815-2833.

Majid A.A., Al-Noori M.A., Al-Anai Ibrahim A., 2019. Effect of adding different levels of anise, fenugreek, anise and fenugreek mixture and sage to the diet on the total bacterial count and colonic bacteria in the intestines of broilers. Indian Journal of Public Health Research \& Development, 10(8): 1930-1934.

Majid R.H., Albashr T.K.M., Hamma A.A., Khidhir Z.K., 2020. Effect of dietary supplementing cumin (Cuminum cyminum L.) on meat traits of the broiler chicks. Basrah Journal of Agricultural Sciences, 33(1): 159-171.

Naidu M.M., Shyamala B.N., Naik J.P., Sulochanamma G., Srinivas, P., 2011. Chemical composition and antioxidant activity of the husk and endosperm of fenugreek seeds. LWT - Food Science and Technology, 44(2): 451-456.

Nguyen P.M., Kwee E.M., Niemeyer E.M., 2010. Potassium rate alters the antioxidant capacity and phenolic concentration of basil (Ocimum basilicum L.) leaves. Food Chemistry,123: 1235-1241.

Nurzyńska-Wierdak R., Borowski B., Dzida K., 2011. Yield and chemical composition of basil herb depending on cultivar and foliar feeding with nitrogen. Acta Scientiarum Polonorum Hortorum Cultus, 10(1): 207-219.

Park J.H., Kang S.N., Shin D., Shim K.S., 2015. Antioxidant enzyme activity and meat quality of meat type ducks fed with dried oregano (Origanum vulgare L.) powder. Asian-Australasian journal of animal sciences, 28(1), 79-85.

Polat U., Yesilbag D., Eren M., 2011. Serum biochemical profile of broiler chickens fed diets containing rosemary and rosemary volatile oil. Journal of Biology Environment Science, 5(13): 23-30.

Quinche A.R.S., Saldarriaga J.C.S., Guerrero J.N.Q., Romero J.R.P., Baena I.P., 2019. Effect of Mentha spicata $L$. infusión on the productive performance and organoleptic characteristics of Cobb 500 broilers. Acta Agronómica, 68(4): 312-318.

Rafiee A., Kheiri F., Rahimian Y., Faghani M., Valiollahi M.R., Miri Y., 2014. The effect of ginger root (Zingiber officinale) and cumin (Cuminum cyminum) powder on performance, some haematological traits and 
intestinal morphology of broiler chicks. Research Opinions in Animal and Veterinary Sciences, 4(2): 96-100.

Rasouli B., Movahhedkhah S., Seidavi A., Haq Q.M.I., Kadim I., Laudadio V., Mazzei D., Tufarelli V., 2019. Effect of sage (Salvia officinalis L.) aqeous leaf extract on performance, blood constituents, immunity response and ileal microflora of broiler chickens, Agroforestry Systems, 94: 1179-1187.

Ri C.S., Jiang X.R., Kim M.H., Wang J., Zhang H.J., Wu S.G., Bontempo V., Qi G.H., 2017. Effects of dietary oregano powder supplementation on the growth performance, antioxidant status and meat quality of broiler chicks. Italian Journal of Animal Science, 16(2): 246-252.

Samani S.K., Ghorbani M.R., Fayazi J. and Salari S., 2020. The effect of different levels of Fenugreek (Trigonella foenum-graecum L.) powder and extract on performance, egg quality, blood parameters and immune responses of laying hens in second production cycle. Veterinary Research Forum, 11(1): 53-57.

Seidavi A.R., Laudadio V., Khazaei R., Puvača N., Selvaggi M., Tufarelli V., 2020. Feeding of black cumin (Nigella sativa L.) and its effects on poultry production and health. World's Poultry Science Journal, 76(2): 346357.

Sheoran N., Kumar R., Kumar A., Batra K., Sihag S., Maan S., Maan N., 2017. Nutrigenomic evaluation of garlic (Allium sativum) and holy basil (Ocimum sanctum) leaf powder supplementation on growth performance and immune characteristics in broilers. Veterinary World, 10(1): 121-129.

Singh P., Pandey A.K., 2018. Prospective of essential oils of the genus Mentha as biopesticides: a review. Frontiers in Plant Science, 9: 1295.

Spiridon I., Colceru S., Anghel N., Teaca C.A., Bodirlau R., Armatu A., 2012. Antioxidant and total phenolic contents of oregano (Origanum vulgare), lavender (Lavandula angus and lemon balm (Melissa officinalis) from Natural Product Research, 25(17): 1657-1661.

SR EN ISO 2171: 2010. Cereals, pulses and by-products - Determination of ash yield by incineration.

SR EN ISO 5983-2: 2009. Animal feeding stuffs - Determination of nitrogen content and calculation of crude protein content - Part 2: Block digestion and steam distillation method.

SR EN ISO 6865: 2002. Animal feeding stuffs - Determination of crude fibre content - Method with intermediate filtration.

SR ISO 6490-1: 2006. Animal feeding stuffs - Determination of calcium content - Titrimetric method.

SR ISO 6492: 2001. Animal feeding stuffs - Determination of fat content.

Toaha S.M., Mollah B.R. and Ahammad M.U., 2016. Use of dietary fenugreek (Trigonella foenum-graecum L.) seed for the production of safe broiler 
lean meat. Research in Agriculture Livestock and Fisheries, 3(2): 305314.

Turcu R.P., Tabuc C., Vlaicu P.A., Panaite T.D., Buleandra M., Saracila M., 2018. Effect of the dietary oregano (Origanum vulgare L.) powder and oil on the balance of the intestinal microflora of broilers reared under heat stress $\left(32^{\circ} \mathrm{C}\right)$. Scientific Papers. Series D. Animal Science, LXI(1): 7786.

Untea A., Criste, R.C., Vladescu L., 2012. Development and validation of a microwave digestion-FAAS procedure for $\mathrm{Cu}, \mathrm{Mn}$ and $\mathrm{Zn}$ determination in liver. Revista de Chimie, 63(4): 341-346.

Untea A.E., Varzaru I., Panaite T.D., Gavris T., Lupu A., Ropotă M., 2020. The Effects of Dietary Inclusion of Bilberry and Walnut Leaves in Laying hens' diets on the antioxidant properties of eggs. Animals, 10, 191.

Varzaru I., Untea A.E. and Saracila M., 2020. In vitro antioxidant properties of berry leaves and their inhibitory effect on lipid peroxidation of thigh meat from broiler chickens. European Journal of Lipid Science and Technology, 122, 1900384.

Velasco V., Bravo P., Williams P., Campos J., Astudillo R., Melín P., 2017. Storage stability of poultry meat from broilers fed with dry oregano (Origanum vulgare L.) in the diet. Chilean Journal of Agricultural \& Animal Sciences (ex Agro-Ciencia), 33(1): 28-38.

Verma P.S., Pandey S., Neeraj, 2020. Performance of caged broilers as influenced by dietary supplementation of Mentha leafs powder and vitamin C. Journal of Experimental Zoology, 23(2): 1881-1886.

Vlaicu P.A., Panaite T.D., Turcu R.P., Tabuc C., 2020. Dietary Origanum vulgare supplements for broilers. Romanian Biotechnology Letters, 25(5): 1922-1929.

Wahab F., Chand N., Khan R.U., Ahmad N., Parvez U., Rehman Z., Naz S., 2019. Dietary supplementation of Fenugreek (Trigonella foenum graecum) on the egg quality characteristics of Rhode Island Red spent layers. Pakistan Journal of Zoology, 51(5): 1793-1797.

Windisch W., Schedle K., Plitzner C. and Kroismayer A., 2008. Use of phytogenetic products as feed additives for swine and poultry. Journal of Animal Science, 86(14): E140-E148.

Yalçin S., Eser H., Onbaşilar Y., Yalçin S., 2020. Effects of dried thyme (Thymus vulgaris L.) leaves on performance, some egg quality traits and immunity in laying hens. Ankara Üniversitesi Veteriner Fakültesi Dergisi, 67(3): 303-311.

Yesuf K., Mersso B., Bekele T., 2017. Effects of different levels of turmeric, fenugreek and black cumin on carcass characteristics of broiler chicken. Journal of Livestock Science (ISSN online 2277-6214), 8: 1117. 